\title{
A Further Understanding of the Dominant Factors Affecting E-learning Usage Resources by Students in Universities in the UAE
}

\author{
Rima Shishakly ${ }^{1^{*}}$ \\ ${ }^{1}$ Ajman University, UNITED ARAB EMIRATES \\ Received 10 July 2021 - Accepted 5 September 2021
}

\begin{abstract}
Universities benefit from the merging of classroom lecturing and the use of technological resources to provide an innovative environment for their students. E-learning resources facilitate the process of teaching and learning. Although students use these resources widely, their usage behaviours and the factors the dominate the instructor-students learning resources usage still need to be investigated further due to the fast growing technological changes and the advance features of e-learning, which affect the dominant prioritization and the significances of these factors. In order to facilitate this research, a research model was derived from the modified Technology Acceptance Model (TAM) in order to observe the factors that influence the instructors-students utilization of learning resources within universities in the United Arab Emirates (UAE). The research model was assessed based on an analysis of 520 students who participated in the study. Thus, it can be inferred that both peer influence and student's capability to use technology have no relevant effect on perceived usefulness and students' usage behaviour. However, instructor contributions, course content and design do indeed have a significant correlation with student usage behaviour. The findings from this research advance the understanding of the factors that have a more dominant influence on instructor-students learning resources usage in the context of UAE universities.
\end{abstract}

Keywords: e-learning, Technology Acceptance Model, United Arab Emirates, Learning Management Systems

\section{INTRODUCTION}

Universities in the UAE, using traditional lecturing, as well as e-learning systems such as 'Moodle' and 'Blackboard' to enhance the delivery of course content (such as PowerPoint slides), access to e-books and elibraries to support their learning processes, provide alternative tools to fit various abilities to learn, as well as upload information. They also facilitate e-submissions for assignments and projects, provide a place for online quizzes, and allow general downloading and uploading of information. AlGahtani (2011) and Zeitoun (2015), agree that E-learning can be used to deliver course materials and share traditional explanations in the classroom setting. El-Seoud et al. (2013, p. 20) state, "Elearning has been introduced as a tool in the learning process in the majority of the international universities worldwide." Numerous challenges affect the actual use of e-learning. Both Tseng (2012) and Almaiah et al. (2020) share the view that there are several boundaries affecting the effectiveness of e-learning usage. It is agreed that these challenges can be attributed to management, technological, implementation, culture, technological, individual and course-related challenges. However, these factors still need further investigation due to the rapid development of e-learning platform technology, and their integration within different countries. Few studies investigate e-learning usage in higher education across the UAE, this is why there is a need for this type of study in the UAE. Al-Hawari and Mouakket (2010) in their study in UAE universities, state that the factors affecting e-learning acceptance are: Design features, enjoyment, and students' e-satisfaction, which has a direct relationship with students' e-retention. Salloum (2018) agree that the perceived ease of use has a significant impact on perceived usefulness, attitudes,

(c) 2021 by the authors; licensee Modestum. This article is an open access article distributed under the terms and conditions of the Creative Commons Attribution License (http://creativecommons.org/licenses/by/4.0/). 


\section{Contribution to the literature}

- Add value to the ongoing existing literature on investigating the factors that further influence the students' e-learning resources usage.

- The TAM model was adapted to further the understanding of its contextual relevance in the UAE's culture and enrich the theoretical framework examining the students' usage behaviour of e-learning.

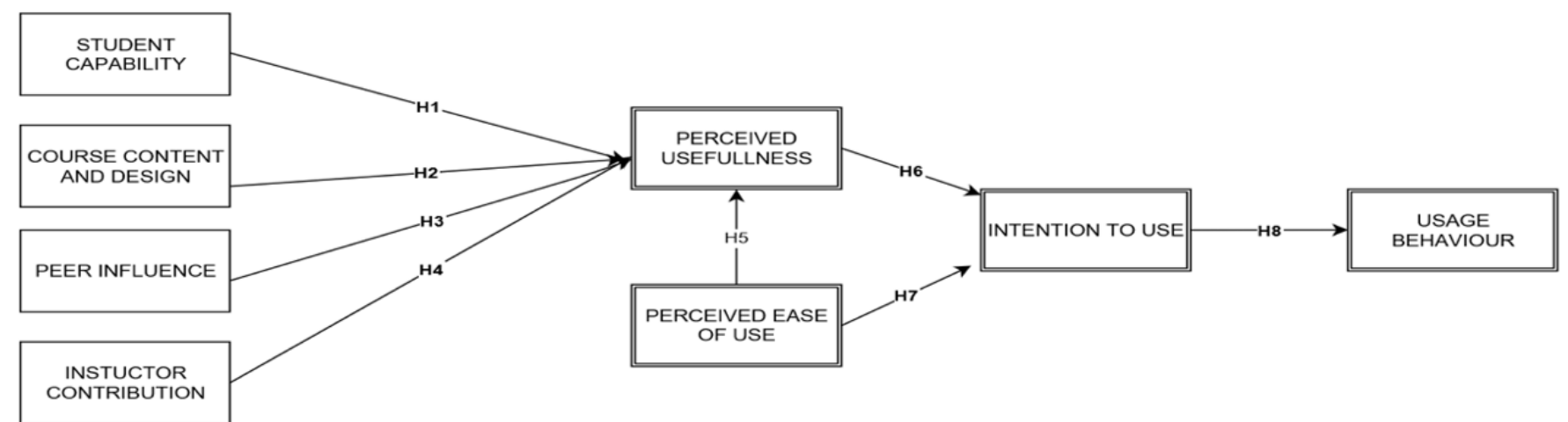

Figure 1. The conceptual framework

and behavioral intention to use e-learning systems. According to Salloum et al. (2019), in their study within the UAE, state that system quality, computer selfefficacy, and computer playfulness are the factors that are having a positive impact on students' perceived ease of use of e-learning systems. Whiles reviewing the previous studies that unpack the challenges that students face, this adds an additional perspective and depth to the understanding of the e-learning usage in the UAE.. Furthermore, the rapid growth of technology advances, and the development of e-learning features in the educational field in different countries, as well as UAE. The study is focusing on the factors that challenging the instructor-students e-learning resources usage. These factors are students' capability to use the technology, course content and design, peer influence, and instructors' contribution. The study will examine which factors are more dominant, and significantly influence instructors-students e-learning resources usage in the context of UAE universities. As these are overarching factors, this study strives to answer a fundamental question: what are the dominant factors that affect the instructors-students' use of e-learning resources in UAE universities? The study objectives are to conceptualize and empirically examine these factors. The structure of this paper explores the proposed hypotheses as an overview with prior studies, followed by the research method, the data analysis, the presentation of results and finally, the study's contributions, implications, limitations, and directions for future research.

\section{Research Hypotheses}

The following section draws on the e-learning factors and the students' Usage Behaviour (UB), to develop testable hypotheses, theoretical concepts including variables in the Technology Acceptance Model (TAM) (Davis et al., 1989). According to Davis et al. (1989, p. 985-986), Perceived Ease Of Use (PEOU) "refers to the degree to which the prospective user expects the target system to be free of effort by using specific technology". Perceived Usefulness (PU) is defined as "the prospective user's subjective probability that using a specific application system will increase his or her job performance". Al-Qaysi (2018) agrees that TAM in educational technology acceptance has shown its efficiency as compared to the other theoretical models. However, many researchers have adopted TAM model in the field of education to examine the students' usage behaviour of e-learning and have applied it in many countries and cultures (Chang et al., 2017; Chen \& Li, 2018; Fathema et al., 2015; Salloum et al., 2019). Accordingly, Figure 1 is presenting the study hypotheses. These hypotheses denote the students' capabilities to use e-learning resources on their perceived usefulness of e-learning resource (H1). Course content and design and students' perceived usefulness of e-learning resource $(\mathrm{H} 2)$, and peer influence effects on the perceived usefulness of e-learning resources usage $(\mathrm{H} 3)$, the instructors' contribution influence on perceived usefulness of e-learning resource usage $(\mathrm{H} 4)$, students' perceived ease of use influence their perceived usefulness of e-learning resources. (H5), perceived usefulness influences on the students' intention to use Elearning resources (H6), perceived ease of use influences on the students' intention to use E-learning resources (H7) and the influence of students' intention to use elearning on students' usage behaviour of e-learning resources $(\mathrm{H} 8)$. 


\section{REVIEW STUDIES ON E-LEARNING EFFECTED FACTORS}

The term "e-learning" has become very popular. Elearning is online-distance learning, as well as hybrid learning, and it is used as a component of an instructional delivery system (Arkorful \& Abaidoo, 2014; Chunjuan \& Zongxiang, 2016; Oblinger \& Hawkins, 2005). Accordingly, Keller and Suzuki (2004), Bares (2008), Sangrà et al. (2012), and Paechter et al. (2020) agree that using e-learning in education has a substantial growth, and it is part of the new dynamic that characterizes the education system at the start of the 21st century. The literature review indicates numerous studies have mentioned several challenges affecting students' e-learning usage behavior. These challenges could be classified into various factors. According to AlGahtani (2016), in Saudi Arabia, found that the most significant factors determinants of e-learning acceptance were playfulness, self-efficacy and anxiety, perceptions of external control, subjective norms, and perceived usefulness. Kanwal and Rehman (2017) state three main challenges that hamper the usage of e-learning systems, namely, change management issues, e-learning system technical issues, and financial support issues. However, these factors still need further investigation due to the fast-growing of technological e-learning platforms, technological availability, and integration of e-learning within different countries. However, these factors may differ from one country to another. Moreover, e-learning usage challenges are very different from one country to another country due to different cultures, contexts, and students' readiness (Almaiah, 2018; Almaiah et al., 2020; Almaiah \& Alismaiel, 2019; Almaiah \& Jalil, 2014; Alshammari \& Rosli, 2016; Baker, Al Gahtani, \& Hubona, 2010; Chien, 2012; Harandi, 2015; Holden, 2011; Salloum et al., 2019; Shawai, 2018; Zemsky et al., 2004). Since the success of e-learning system depends on students' willingness and acceptance to use this system. This paper will examine the suggested factors highlighted in the paper above to examine the factors that have a more dominant influence on the studentsinstructor e-learning resources usage in the context of the UAE universities. The factors are explained in following sections.

\section{Students Capability (SC)}

SC as a concept refers to the students' ability, skills, and self-efficiency to utilize e-learning resources provided by universities. Chien (2012) and Holden (2011) both agree that computer self-efficacy has often been regarded as vital concepts in the further adoption of technological studies. Thatcher and Perrewé (2002) postulate that computer self-efficacy refers to an individual's judgment regarding their ability to use computers in various different situations. Abbad et al. (2009) and Al-Adwan et al. (2013) agree that students who are confident in their ability to self-sufficiently master an e-learning system are more likely to become users of said e-learning system. Schunk et al. (2014) reveals that self-efficacy is a dominant predictor of performance and student motivation. Therefore, it is important to understand the students' computer selfsufficiency and their ability to use e-learning resources while measuring their propensity to adopt technology and use e-learning resources for their own respective learning processes. Herein, the following hypothesis is proposed:

H1: Students' capabilities to use e-learning resources positively influence their perceived usefulness of e-learning resource.

\section{Course Content and Design (CCD)}

The CCD in this paper refers to the accuracy, sufficiency, and quality of course materials design to supplement course objectives and course learning outcomes. Junus et al. (2015) point out that Content Quality (CQ) refers to the accuracy of used terms, the sufficiency of materials to support the course objectives and the relevance of information. Zaharias and Poylymenakou (2009) agree that the content of elearning systems should be prepared in a suitable sequence and provide adequate resources. Waheed et al. $(2015$, p. 3) agree "that the course structure and contents are according to the needs of the students. It enhances their motivation to use the e-learning portal." They add, "Students find it convenient to use the online assignment submission module, which saves their time and resources like printing and traveling costs" (p. 8). Consequently, the following hypotheses are proposed.

H2: Course Content and Design positively influence students' perceived usefulness of e-learning resource.

\section{Peer Influence (PI)}

PI refers to the inspiration, communication, and collaboration between the students in the universities with or without the instructors' supervision. Boud et al. (1999) defines peer learning as the inter-collegial learning of students without immediate intervention of a professor and/or their assistants. According to Jung et al. (2002, p. 153), "collaborative interaction between peer students are important in enhancing learning and activate participation in the online discussion." Paechter et al. (2010) agree that students working in small groups could benefit in many ways, such as to construct a more efficient understanding between each other, which may motivate the students to do better in an e-learning environment. However, Juwah (2006) argues that the mastery of digital tools is important for facilitating better outcomes with regards to peer interaction. Abbad et al. (2009) and Al-Adwan et al. (2013) claim that student's acceptance of e-learning is dependent on encouragement 
from their peers and/or instructors. Therefore, the following hypotheses is proposed:

H3: Peer influence positively affects the perceived usefulness of e-learning resources usage.

\section{Instructor Contributions (IC)}

IC, referring to the instructors' presence and interaction with students, has shown to positively relate to student learning and motivation (Baker et al., 2010). With e-learning, instructors' schedules are redefined, as well as their duties and relationships towards students (Young, 2002). According to Harandi (2015), a significant learning component within this platform is an open communication between student and their respective professor. Anderson and Gronlund (2009) ensure that instructional quality is significantly related to students' overall satisfaction with the self-paced and online course. Vonderwell and Zachariah (2005, p. 222) "indicated that online learner participation and patterns of participation were influenced by the following factors: technology and interface characteristics, content-area experience, student roles, and instructional tasks, and information overload." According to Sorebo et al. (2009) unwillingness of the educators to utilize e-learning may lead to underutilization by students and possibly reduce the learning outcomes. Yildrim (2000) observes that inefficient or lackluster technology will create friction in the learning process and, hence, will discourage the use of aforementioned technology for their students and refrain from using it themselves. Therefore, the following hypothesis is proposed:

H4: Instructors' contribution influence positively the perceived usefulness of e-learning resource usage.

\section{Perceived Ease of Use (PEOU)}

PEOU can be defined as "the degree to which a person believes that using a particular technology would be free from effort" (Davis, 1989, p. 320; Davis et al., 1989). According to Lu et al. (2003), PEOU as the user's ability to understand the information system and how quickly they can manage its usage efficiently, and without confusion or tribulation. According to Sun et al. (2008, p. 52), Davis (1989), and Liu et al. (2010), when individuals think that technology skills is easy to use, they will be inclined to work with it. Hence, the following hypothesis is proposed.

H5: Students' perceived ease of use e-learning resources influences their perceived usefulness of e-learning resources positively.

\section{Intention to Use (IU)}

Another factor regarding technology adoption is IU. Davis (1989) and Liu et al. (2010) postulate that ease of use correlates to the readiness to implement said technology. Huang and Liaw (2005) who add that positive opinions regarding the technology facilitate greater engagement with the e-learning system that utilizes this technology further support this. Sun et al. (2008) correlates positive attitudes towards the technology and its perceived IU for online learning methods. According to Abdel-Wahab (2008) intentions to use, e-learning is influenced by consistent access to elearning (i.e., speedy Internet connection with affordable costs, the essential equipment). IU is seen to mediate the relationship between the actual usage behavior and perceived ease of use and perceived usefulness (PU) respectively. PU can be defined as the degree to which an individual believes that using a specific system would improve the job performance (Davis, 1989). Consequently, Liu et al. (2010) suggest that PU is related to the belief that a technology enhances an individual's 'performance. Nath et al. (2014) show that PU influences a person's attitude towards using their technology. Therefore, the hypothesis is stated as:

H6: Perceived usefulness has a positive influence on the students' intention to use e-learning resources

H7: Perceived ease of use has a positive influence on the students' intention to use e-learning resources.

\section{Usage Behavior (UB)}

UB is referring to the student's behaviour when using e-learning resources among the students in the selected universities. According to Ajzen and Fishbein (2005), UB drives behaviour and refers to the way that individuals respond to or ignore an object. More importantly, any efforts exerted to heavily implement e-learning relies on the involvement of users' attitudes. Ajzen and Fishbein (2005) add that usability factors used as a reference in eLearning system usability evaluation are designed to accommodate all parameters Turner et al. (2010) mention that behavioural intention is a good predictor for actual system use in both subjective and objective measurement. Thus, the following hypothesis is proposed:

H8: Students' IU e-learning resources positively influences students' UB of e-learning resources.

\section{RESEARCH METHODOLOGY}

This study used quantitative methods of data collection to empirically examine and underline the factors that had a greater influence on the instructorsstudents' usage behavior of the e-learning resources such as PowerPoint slides, e-submissions for assignment and projects, quizzes online and access to e-books and elibraries. Non-probability sample was adopted, which is commonly used in the higher education field (e.g., Bokolo Jr et al., 2020; Moore et al., 2011; Zainab et al., 2017), The study was used to target the respondents who 
Table 1. Sources of constructs

\begin{tabular}{|c|c|c|c|c|}
\hline Construct & Item & Mean & S.D. & Reference \\
\hline $\begin{array}{l}\text { Perceived } \\
\text { usefulness (PU) }\end{array}$ & $\begin{array}{l}\text { - Using e-learning resources facilitates the online } \\
\text { submission of assignments and projects. } \\
\text { - Using e-learning resources facilitates the uploading of all } \\
\text { my assignments, quizzes and projects online. } \\
\text { - Using e-learning resources enhances the quality of online } \\
\text { learning processes. }\end{array}$ & 3.96 & 0.97 & $\begin{array}{l}\text { Salloum et al. (2019) Chang et al. } \\
\text { (2017); Fathema et al. (2015); } \\
\text { John (2015); Ong and Lai (2006); } \\
\text { Roca et al. (2006) }\end{array}$ \\
\hline $\begin{array}{l}\text { Students' } \\
\text { capability (SC) }\end{array}$ & $\begin{array}{l}\text { - I have the skills to learn how to use e-learning facilities. } \\
\text { - I am capable of using the different facilities that support } \\
\text { my learning process (banners, e-books, and e-libraries). }\end{array}$ & $\begin{array}{l}3.99 \\
3.86\end{array}$ & $\begin{array}{c}0.95 \\
0 / 98\end{array}$ & $\begin{array}{l}\text { Thatcher and Perrewé (2002); } \\
\text { Lin et al. (2010); Park (2009); } \\
\text { Fathema et al. (2015) }\end{array}$ \\
\hline $\begin{array}{l}\text { Course content } \\
\text { and design } \\
(\mathrm{CCD})\end{array}$ & $\begin{array}{l}\text { rial is clear and well structured. } \\
\text { nt is full of knowledge. } \\
\text { nt is well designed. }\end{array}$ & $\begin{array}{l}3.66 \\
3.69 \\
3.64\end{array}$ & $\begin{array}{l}0.97 \\
0.95 \\
0.97\end{array}$ & $\begin{array}{l}\text { Junus et al. (2015); Singh et al. } \\
\text { (2005); Govender and Rootman- } \\
\text { le Grange (2015); Calisir et al. } \\
\text { (2014); Cheng (2011) }\end{array}$ \\
\hline fluence & $\begin{array}{l}\text { ink you use el-earning resources because of your } \\
\text { ommendations? } \\
\text { oeer motivate you to use e learning? } \\
\text { ink that without your peers' help, you are not } \\
\text { the e-learning facilities? }\end{array}$ & $\begin{array}{l}3.09 \\
2.72\end{array}$ & $\begin{array}{l}1.12 \\
1.20\end{array}$ & $\begin{array}{l}\text { Lay and Chen (2011); Shen et al. } \\
\text { (2006) }\end{array}$ \\
\hline $\begin{array}{l}\text { or } \\
\text { ition (IC) }\end{array}$ & $\begin{array}{l}\text { expertise in the implementation of e- } \\
\text { s. } \\
\text { s high expertise in the usage of e-learning. } \\
\text { courages my e-learning usage. }\end{array}$ & $\begin{array}{l}3.49 \\
3.59\end{array}$ & $\begin{array}{l}1.06 \\
1.10\end{array}$ & d et al. (2014); Qteishat et \\
\hline $\begin{array}{l}\text { Perce } \\
\text { of us }\end{array}$ & $\begin{array}{l}\text { - I find that e-learning resources are easy to access. } \\
\text { - I find that e-learning resources are easy to use. } \\
\text { - I find that e-learning resources are understandable and do } \\
\text { not require mental effort. } \\
\text { - I find that e-learning elements are well structured and } \\
\text { designed. }\end{array}$ & $\begin{array}{l}3.91 \\
3.96 \\
3.93 \\
3.88\end{array}$ & $\begin{array}{l}0.89 \\
0.87 \\
0.91\end{array}$ & $\begin{array}{l}\text { Salloum et al. (2019); Nafsaniath } \\
\text { and Shannon (2015); Fathema et } \\
\text { al. (2015); Ong and Lai (2006); } \\
\text { Park (2009) }\end{array}$ \\
\hline $\begin{array}{l}\text { Inter } \\
\text { (IU) }\end{array}$ & $\begin{array}{l}\text { I intend to use e-learning resources to assist my learning } \\
\text { processes. } \\
\text { - I intend to use e-learning resources to facilitate the } \\
\text { learning processes. }\end{array}$ & $\begin{array}{l}3.58 \\
3.62 \\
3.65\end{array}$ & 1.04 & $\begin{array}{l}\text { Cheung and Vogel (2013); } \\
\text { Mohammadi (2015); Teo and } \\
\text { Zhou (2014); Nafsaniath and } \\
\text { Shannon (2015) }\end{array}$ \\
\hline $\begin{array}{l}\text { Usage behaviou } \\
\text { (UB) }\end{array}$ & $\begin{array}{l}\text { - I use e-learning resources for a long duration. } \\
\text { - I use e-learning resources for a short duration. } \\
\text { - I use e-learning resources frequently. } \\
\text { - I cannot study without using e-learning resources. }\end{array}$ & $\begin{array}{l}3.47 \\
2.64 \\
3.56 \\
3.26\end{array}$ & $\begin{array}{l}1.09 \\
1.15 \\
1.08 \\
1.19\end{array}$ & $\begin{array}{l}\text { Al-Harbi (2011); Cheung and } \\
\text { Vogel (2013); Mohammadi } \\
\text { (2015); Al-Gahtani et al. (2007); } \\
\text { Al-Gahtani (2008) }\end{array}$ \\
\hline
\end{tabular}

were students in the universities and were also using the e-learning systems resources provided by their universities. According to the findings of Krejcie and Morgan (1970), 375 is the minimum sample size for a population of 15000 . At the time of gathering the data, 14000 individual students were enrolled across three universities and, thus, questionnaires used for the purpose of the research were distributed across all enrolled students at the time.

\section{Measures}

Squares-Structural Equation Modelling (SEM) was utilized to process the data of the developed model. Utilizing SEM will ensure more accurate estimates as it provides a concurrent level of analysis for both the structural model and measurements provided (Barclay et al., 1995). Moreover, SEM provides a more thorough method by which to test hypotheses relating observed and latent variables (Hoyle \& Panter, 1995). SEM is the most prevalent approach when measuring the level of information technology acceptance by users. Several published studies have adopted the TAM and TAM2 (Al-Gahtani, 2008, 2011; Al-hawari \& Mouakket, 2010; Alshammari et al., 2016; Salloum, 2018; Salajan et al., 2015; Salloumi et al., 2019; Venkatesh, 1999; Venkatesh \& Davis, 2000; Venkatesh et al., 2003). A survey instrument was developed, to test the hypothesis presented in the research, the survey contained nineteen closed-ended questions. Table 1 presents the sources of these constructs. The questions from the earlier studies were modified to make them consistent with the requirements of the current study.

\section{Sample and Data Collection}

The study was conducted in three private universities within the UAE, namely, Ajman University (AU), University of Sharjah (UoS) and City University College of Ajman (CUCA). These universities are in close proximity to each other as AU and CUCA are both located in the Emirate of Ajman. Although also in close 
Table 2. Respondent profiles $(n=520)$

\begin{tabular}{llcc}
\hline Profile & Item & Frequency & Percentage (\%) \\
\hline Gender & Male & 183 & 35.2 \\
& Female & 285 & 54.8 \\
& Business School & 211 & 40.5 \\
& Mass communications & 73 & 14.0 \\
& Engineering \& IT & 32 & 6.2 \\
& Law & 43 & 8.3 \\
& Architecture & 41 & 7.9 \\
& Humanities and Science & 41 & 7.9 \\
Year of Study & Dentistry & 30 & 5.8 \\
& Pharmacy & 35 & 6.7 \\
& Medicine & 14 & 2.7 \\
& Year 1 & 105 & 20.1 \\
& Year 2 & 99 & 19.1 \\
& Year 3 & 153 & 29.5 \\
\end{tabular}

proximity, UoS is situated within the neighbouring Emirate of Sharjah. In addition, all aforementioned universities employ similar Learning Management Systems (LMS). Pilot-tested questionnaires were distributed to these universities in order to collect data. The purpose for pilot testing these questionnaires was two-fold: observing the reliability of the questionnaire items and confirming that respondents can easily understand the questionnaire items. Care was placed into ensuring that structure, language and clarity was to an acceptable standard. These surveys were distributed directly to undergraduate students across three universities using a non-probability sampling approach. Data was collected from these students, who were all undergraduate students, who came from of different colleges, different academic years, males and females. This also ensured that the factor of age was not a variable when examining usage behaviour in this study. Within three weeks of the 540 responses that were collected, it was determined that 520 were appropriate and usable. The questionnaire items were divided into eight sections; the first section focused on gathering personal information at the discretion of the respondents. The second containing items pertaining to e-learning system resources and their utilization by respondents. Items were measured using a five-point Likert scale where the lowest score (1) refers to "strongly disagree," and the highest score (5) refers to "strongly agree" with nineteen questions adapted from similar research on technology acceptance (Davis et al., 1989; Venkatesh et al., 2003). The external variables were PU, PEOU, IU, UB. IC, CCD, PI, and IC are modified variables to fit research purposes.

\section{Respondents}

Table 2 sorts the respondents' profiles in relation to their gender, college, and year of study. The first section asked questions about the participants' demographic questions, which are summarised in Table 2.

\section{Evaluation of the Research Model}

The research model was evaluated by considering the internal consistency, or Composite Reliability (CR), indictor reliability, convergent validity and discriminant validity (Hair et al., 2014). The CR scores summarized in Table 3 indicated that these constructs should be consistent, since all constructs met the recommended threshold value for acceptable reliability, that is, both CR and Cronbach's a should be greater than 0.70 . The first test was to analyse Fornell-Larcker criterion (Hair et al., 2013) to evaluate if the square root of Average Variance Extracted (AVE) value (diagonal elements) for each construct was greater than the correlation of the construct with any other construct (off-diagonal elements), which was true based on the comparison summarized in Table 4.

The purpose of the second test was to examine if each indication loaded highest on its respective construct, which in turn, was also true, therefore, it can be concluded that discriminant validity was satisfactory.

\section{Hypotheses Testing}

In order to test the hypotheses, Smart PLS was implemented. A bootstrapping procedure (5000 samples) (Hair et al., 2014) was used to assess the research model. Figure 2 provides the results of the analysis in order to understand if UB was affected by alternative variables. This study was controlled for student gender, college and year of study by the utilization of dummies. It is observed that there was no statistically significant effect on academic performance by any of the control variables.

Table 5 shows the standardized path coefficient and p-value of each hypothesized path where it is applicable. H1 suggested that Students' Capabilities (SC) to use technology influence positively their PU of e-learning 
Table 3. Convergent validity and internal consistency reliability

\begin{tabular}{|c|c|c|c|c|c|c|}
\hline Construct & Indicators & Loading & Indicator Reliability & Cronbach's alpha & Composite Reliability & AVE \\
\hline \multirow[t]{3}{*}{$\overline{C C D}$} & CCD1 & 0.88 & 0.77 & \multirow{3}{*}{0.88} & \multirow{3}{*}{0.92} & \multirow{3}{*}{0.80} \\
\hline & CCD2 & 0.91 & 0.83 & & & \\
\hline & CCD3 & 0.89 & 0.79 & & & \\
\hline \multirow[t]{3}{*}{ IC } & IC1 & 0.92 & 0.85 & \multirow{3}{*}{0.90} & \multirow{3}{*}{0.94} & \multirow{3}{*}{0.84} \\
\hline & IC2 & 0.94 & 0.88 & & & \\
\hline & IC3 & 0.89 & 0.79 & & & \\
\hline \multirow[t]{3}{*}{ IU } & IU1 & 0.92 & 0.85 & \multirow{3}{*}{0.90} & \multirow{3}{*}{0.94} & \multirow{3}{*}{0.83} \\
\hline & IU2 & 0.91 & 0.83 & & & \\
\hline & IU3 & 0.91 & 0.83 & & & \\
\hline \multirow[t]{4}{*}{ PEOU } & PEOU1 & 0.93 & 0.86 & \multirow{4}{*}{0.93} & \multirow{4}{*}{0.95} & \multirow{4}{*}{0.83} \\
\hline & PEOU2 & 0.94 & 0.88 & & & \\
\hline & PEOU3 & 0.90 & 0.81 & & & \\
\hline & PEOU4 & 0.88 & 0.77 & & & \\
\hline \multirow[t]{3}{*}{ PI } & PI1 & 0.81 & 0.66 & \multirow{3}{*}{0.79} & \multirow{3}{*}{0.87} & \multirow{3}{*}{0.69} \\
\hline & PI2 & 0.90 & 0.81 & & & \\
\hline & PI3 & 0.78 & 0.61 & & & \\
\hline \multirow[t]{3}{*}{ PU } & PU1 & 0.91 & 0.83 & \multirow{3}{*}{0.88} & \multirow{3}{*}{0.92} & \multirow{3}{*}{0.80} \\
\hline & PU2 & 0.89 & 0.79 & & & \\
\hline & PU3 & 0.89 & 0.79 & & & \\
\hline \multirow[t]{2}{*}{ SC } & SC1 & 0.94 & 0.88 & \multirow{2}{*}{0.85} & \multirow{2}{*}{0.93} & \multirow{2}{*}{0.87} \\
\hline & SC2 & 0.93 & 0.86 & & & \\
\hline \multirow[t]{2}{*}{ UB } & UB1 & 0.86 & 0.74 & \multirow{2}{*}{0.71} & \multirow{2}{*}{0.87} & \multirow{2}{*}{0.78} \\
\hline & UB2 & 0.90 & 0.81 & & & \\
\hline
\end{tabular}

Table 4. Inter-construct correlations

\begin{tabular}{llllllll}
\hline & CCD & IC & IU & PEOU & PI & PU & SC \\
\hline CCD & $\mathbf{0 . 8 9}$ & & & & & & \\
IC & 0.47 & $\mathbf{0 . 9 2}$ & & & & & \\
IU & 0.42 & 0.63 & $\mathbf{0 . 9 1}$ & & & & \\
PEOU & 0.59 & 0.44 & 0.53 & $\mathbf{0 . 9 1}$ & & & \\
PI & 0.26 & 0.44 & 0.43 & 0.21 & $\mathbf{0 . 8 3}$ & & \\
PU & 0.53 & 0.54 & 0.48 & 0.62 & 0.32 & $\mathbf{0 . 8 9}$ & $\mathbf{0 . 9 3}$ \\
SC & 0.65 & 0.43 & 0.32 & 0.55 & 0.14 & 0.43 & 0.30 \\
UB & 0.41 & 0.47 & 0.53 & 0.49 & 0.35 & 0.40 & $\mathbf{0 . 8 8}$ \\
\hline
\end{tabular}

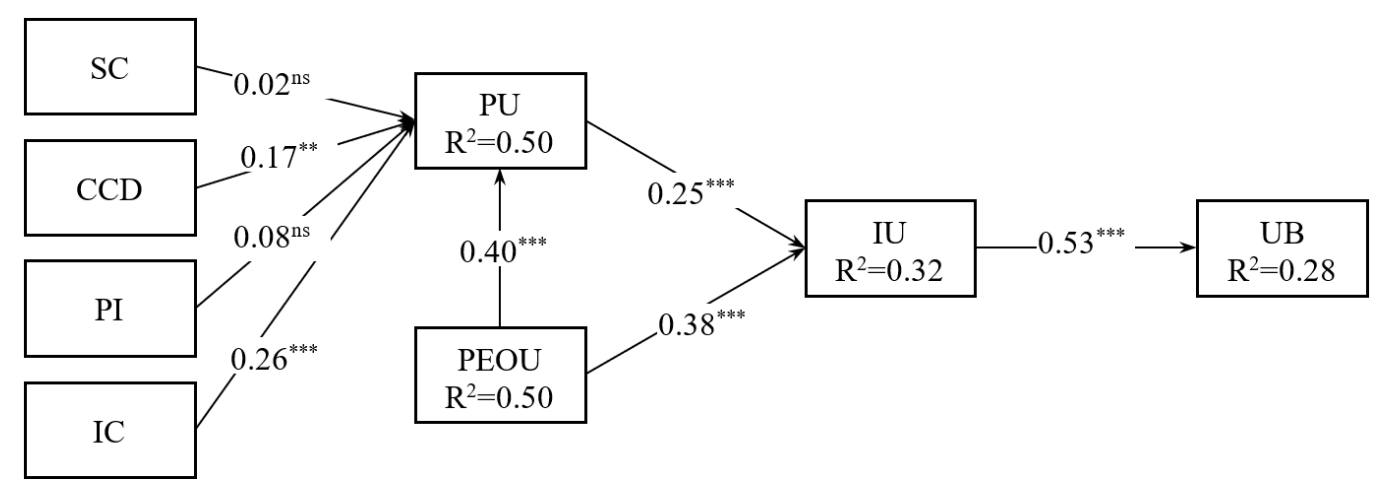

Figure 2. Test results of hypotheses

${ }^{* * *} p<0.001,{ }^{* *} p<0.01,{ }^{*} p<0.05$, ns=not significant

Table 5. Summary results of hypotheses testing

\begin{tabular}{|c|c|c|c|}
\hline Hypothesis & Hypothesized Path & Effect & Empirical evidence \\
\hline $\mathrm{H} 1$ & SC- $>$ PU & $0.02^{\mathrm{ns}}$ & No \\
\hline $\mathrm{H} 2$ & CCD->PU & $0.17^{* *}$ & Yes \\
\hline $\mathrm{H} 3$ & PI->PU & $0.08^{\mathrm{ns}}$ & No \\
\hline $\mathrm{H} 4$ & IC->PU & $0.26^{* * *}$ & Yes \\
\hline H5 & PEOU->PU & $0.40^{* \star *}$ & Yes \\
\hline H6 & PU->IU & $0.25^{\star \star *}$ & Yes \\
\hline $\mathrm{H} 7$ & PEOU->IU & $0.38^{\star \star \star *}$ & Yes \\
\hline H8 & IU->UB & $0.53^{\star * *}$ & Yes \\
\hline \multicolumn{4}{|c|}{${ }^{* * *} p<0.001,{ }^{* *} p<0.01,{ }^{*} p<0.05, \mathrm{~ns}=$ not significant } \\
\hline
\end{tabular}


resources usage. As the effect of SC on PU was 0.02 and not significant; thus, $\mathrm{H} 1$ was rejected.

H2 proposed that Course Content and Design (CCD) has a positive influence on students' PU of e-learning resources usage, which was supported as CCD's effect on PU was $0.17(\mathrm{P}<0.01)$. H3 posited that PI positively affect PU of e-learning resources usage, which was rejected as PI's effect on PU was 0.08 and insignificant. $\mathrm{H} 4$ hypothesized that IC influences positively the PU of e-learning resources usage, and the effect of IC on PU was a significant $0.26(\mathrm{p}<0.001)$; thus, $\mathrm{H} 4$ was supported. H5 suggested that students PEOU of e-learning resources positively affects their PU of e-learning resources, which was supported since PEOU's effect on PU was a significant $0.38(\mathrm{p}<0.001)$. H6 assumed that PU has a positive influence on the students' IU, which was proved since PU had a significant effect of $0.25(p<0.001)$ on IU. H7 suggested that PEOU had a positive influence on students' IU of e-learning resources and the PEOU's effect on IU was a significant 0.38 ( $p<0.001$ ); thus, H7 was approved. $\mathrm{H} 8$ assumed that students' IU affects their UB of e-learning resources, which was supported as IU had a significant effect of $0.53(p<0.001)$ on UB.

\section{DISCUSSION AND IMPLICATIONS}

\section{Discussion}

Significant results by determining the most prevalent factors affecting the adoption of e-learning: self-efficacy, subjective norm, enjoyment, computer anxiety and experiences were reached by Abdulla and Ward (2016). However, the findings of this research show that the less dominant factors that determine the instructorsstudents' e-learning resources usage in universities are: students' capability and peer influence, which do not influence their perceived usefulness of e-learning resources usage. While the factors, such as instructor contributions, course content and design are shown to influence students' e-learning resources usage behaviour the most in UAE universities. The finding appears to be consistent with previous research that has shown no significant positive effect exerted by peer influence on perceived usefulness (Lay \& Chen, 2011; Shen et al., 2006). It can be concluded that there is no significant correlation between user's intention to use computers and computer anxiety because effort expectancy is the primary factor. This is supported by the study of Venkatesh et al. (2003). This might be inconsistent with the foundation of the study done in the UAE universities by Salloumi et al. (2019) which indicates that computer self-efficacy was an extensively used factor. Cheng et al. (2017), Fathema et al. (2015), and Schunk et al. (2014) share the view that there is a significant and positive correlation between 'selfefficacy' and the students' perceived ease of use of elearning. With regard to the Course Content and Design (CCD) has a positive influence on Perceived Usefulness
(PU). It is indicative of this study that a student's attitude towards using e-learning resources in influenced by course content and design. The finding is consistent with previous research that indicates that there is a significant impact of content quality on perceived usefulness (Calisir et al., 2014; Cheng, 2011; Govender \& Grange, 2015; Rym et al., 2013).

The study indicates the IC positively affects perceived usefulness. The finding clarifies that instructors' encouragement to use e-learning resources is essential for the students' motivation to use e-learning. This is consistent with the study of Abu El-Seoud et al. (2014). They agree that e-learning success in higher education depends on the effectiveness of delivery and adequate training of instructors in the adoption of elearning initiatives. With respect to the assumption that students' PEOU, the study shows that PEOU has a direct and positive influence on students' PU in the context of students' usage of the e-learning resources. The finding is consistent with the findings of previous studies. Key factors when it pertains to assessing the behavioural intention of e-learning by students and teachers are perceived ease of use and perceived usefulness of social media networking. This is supported by a study in Libya conducted by Elkaseh et al. (2016) in relation to Libyan higher education. AlRabbi (2016), who states that the intention to use technology in the state of Kuwait is also positively influenced by the aforementioned factors, including self-efficacy and attitude, shares the opinion. Regarding the impact of the students UB of e-learning resources, the finding showed that e-learning resources usage is positively related to students' IU. Consequently, this supports the finding in previous studies using TAM in Jordan who agree that perceived usefulness and perceived ease of use of technology are relatively straightforward and positively influence the usage behaviour (Qteishat et al., 2013). This study is in agreement with various studies, which also determine that behavioural intention shows direct and significant influence on actual usage of e-learning systems (AlGahtani, 2016; Al Harbi, 2010; Cheng, 2011; Khor, 2014; Mohammadi, 2015).

\section{Contribution and Implication}

Further investigation of the usage of e-learning system resources is required. This can be attributed to the ongoing and rapid growth of technology dependence and the ongoing developments within the educational sector worldwide. In context of the UAE, additional factors included in the model is supported by the utilization of TAM. Moreover, this study can be considered an added value to the existing literature, through investigating the factors that further influence the instructors-students' e-learning resources usage that are provided by their universities to enhance their learning processes anytime and anywhere. Based on the results of the study, a deeper understanding of external 
factors between instructor and learner was facilitated in addition to providing insight for university managers, designers, system developers and related professionals. Although technology is utilised to an effective degree within the UAE and its higher-education institutions, more attention must be directed towards the factors that hold a relevant role in aiding student usability of elearning systems in order to further improve the performance and efficiency between students and instructors. It can be noted that the study finding offers a deeper understanding of the dominant and significant factors that influence the instructor-students learning resources usage in universities within the UAE.

Secondly, the study shows there are universal analyses with regards to the factors and challenges that impact instructors-students' acceptance usage of elearning, such as students' capability to use technology, management challenges, and implementation challenges, cultural, self-efficacy, peer influence, courses' design, instructors' contribution and financial constraints. These factors have been categorised in a variety of ways, depending on the perspective of the study. Within this study, the two most significant factors that dominated the outcome were instructor contributions, course content and design. While the factors that were the most insignificant were students' capability and peer influence.

Thirdly, on the managerial level, the outcome of this study permits us to make recommendations to the universities' managers, developer, designers, and decision-makers, to promote the use of e-learning; by ensuring system quality and modifying the system functionality; This can lead to a better quality of the course content and improved usage of e-learning resources among the students.

The students' capability or students' self-efficiency does not influence students' Perceived Usefulness perhaps due to the fact that e-learning is user-friendly. However, students are able to learn of their own accord and their technological background and skills are enough to support their self-study while using the elearning resources efficiently and effectively- such as access to PowerPoint slides, e-book, or submission of homework assignments. However, the ability to utilize e-learning resources comes also from the experience dictated by the instructor's implementation of e-learning in their respective courses. Continuous improvement in the e-learning resources and even more user-friendly, easy accessibility and reliability are important areas to focus on. An example of such improvements includes a dedicated application that can be installed on student's personal computers by which to organise and dedicate e-learning resources without the use of the respective LMS websites. Rather, having a dedicated hub for all LMS e-learning resources.
Based on the findings within this study, there is a notable effect of intention of use on e-learning as it correlates student usage behaviour, perceived ease of use and perceived usefulness. Therefore, the systems developers, designers and universities should consider the systems' accessibility, functionality, interactivity, audio and video facilities to ensure students' engagement and usage intention more effectively and efficiently. An example of prolonging student retention and engagement would be to mimic elements used in popular social media applications. The reasoning for this is two-fold; these applications are already focused on optimisation in both the information systems category and the user-retention category. In addition to being more palatable to students and their various social media interests. The above-mentioned strategies will cause disruptive innovations in the education delivery system in the long term.

Finally, state-of-the-art technology will continue to be used in the UAE while rendering former e-learning systems redundant. Thus, it is paramount that ongoing research into said technology must be maintained in perpetuity as well as furthering the understanding of the most relevant factors aiding e-learning usage in higher education. The factors influence student e-learning usage and the technology work in tandem with each other and therefore are susceptible to change in terms of priority and adaptability within changing technologies. The adaptability of these technologies will work alongside the e-learning of students in universities and the factors will alter the position of which factors will be dominant. This ordering will influence the students' elearning usage within the universities. The study did not take into consideration the cultural effects as it was not part of the demographic component but would be something to explore in the future. This research is essential in understanding the impact that e-learning usage has on the educational threshold of students the significance of their learning development.

\section{Limitations and Future Research}

Several limitations are acknowledged within this study. In spite of this, this opens avenues to facilitate opportunities for future research. To begin, this study is primarily focused on dominant factors that affect the usage behaviour of e-learning resources regarding students and instructors. However, additional research could deeply examine the common factors approved by majority of the studies that effect students' usage behaviour thereby developing a deeper understanding of the topic, especially that factors such as determination, and prioritization could be changed in relation to different countries worldwide.

Secondly, non-probability samples and its characteristics are not entirely indicative of the general population and, thus, creates inconsistencies in generalizations the study and its findings. Concerning 
using self-reported measures exclusively, the method was applied as a means of measuring attitude and perceptions, and it should have its weaknesses acknowledged as a consequence of its design. In the UAE, its position as a technologically developed nation state and its ability to progress within the technological sphere, will provide an essential point of departure for further research to develop, and will aid in the expansion of e-learning usage research locally, regionally and internationally.

Conclusively, the concept of this study is dependent on quantitative research that is in turn; dependent on survey data to observe relational correlations. Herein, a deeper and richer understanding of the factors that influence student usage behaviour may be facilitated by future qualitative research.

\section{ABBREVIATIONS}

$\begin{array}{ll}\text { AU } & \text { : Ajman University } \\ \text { AVE } & \text { : Average Variance Extracted } \\ \text { CCD } & \text { : Course Content and Design } \\ \text { CR } & \text { : Composite Reliability } \\ \text { CUCA } & \text { : City University College of Ajman } \\ \text { IC } & \text { : Instructor Contributions } \\ \text { IU } & \text { : Intention to Use } \\ \text { LMS } & : \text { Learning Management Systems } \\ \text { PI } & : \text { Peer Influence } \\ \text { PU } & : \text { Perceived Usefulness } \\ \text { PEOU } & : \text { Perceived Ease Of Use } \\ \text { SC } & \text { : Students' Capabilities } \\ \text { SEM } & : \text { Squares-Structural Equation Modelling } \\ \text { TAM } & : \text { Technology Acceptance Model } \\ \text { UAE } & : \text { United Arab Emirates } \\ \text { UoS } & : \text { University of Sharjah } \\ \text { UB } & \text { : Usage Behaviour }\end{array}$

Author contributions: All authors have sufficiently contributed to the study, and agreed with the results and conclusions.

Funding: No funding source is reported for this study.

Declaration of interest: No conflict of interest is declared by authors.

\section{REFERENCES}

Abbad, M. M., Morris, D., Al-Ayyoub, A., \& Abbad, J. M (2009). Students' decisions to use an eLearning system: a structural equation modelling analysis. International Journal of Emerging Technologies in Learning, 4(4), 4-13. https://doi.org/10.3991/ijet. v4i4

Abbad, M., Morris, D., \& De Nahlik, C. (2009). Looking under the Bonnet: Factors affecting student adoption of e-learning systems in Jordan. International Review of Research in Open and Distance
Learning, 10(2), 1-24. https://doi.org/10.19173/ irrodl.v10i2.596

Abdel-Wahab, A. (2008). Modeling students' intention to adopt e-learning a case from Egypt. Turkish Online Journal of Distance Education, 9(1), 157-168. https:/ / doi.org/10.1002/j.1681-4835.2008.tb00232.x

Abdullah, F., \& Ward, R. (2016). Developing a General Extended Technology Acceptance Model for ELearning (GETAMEL) by analysing commonly used external factors. Computers in Human Behavior, 56, 238-256. https:/ / doi.org/10.1016/j.chb.2015.11. 036

Abou El-Seoud, M. S., Taj-Eddin, I. A., Seddiek, N., ElKhouly, M. M., \& Nosseir, A. (2013). E-learning and students' motivation: A research study on the effect of e-learning on higher education. International Journal of Emerging Technologies in Learning, 9(4), 2026 https:/ / doi.org/10.3991/ijet.v9i4.3465

Abu, F., Rozelan Yunus, A., Abdul Majid, I., Jabar, J., Aris, A., Sakidin, H., \& Ahmad, A. (2014). Technology Acceptance (TAM): Empowering smart customer to participate in electricity supply. Journal of Technology Management and Technopreneurship, 2(1), 85-94.

Ajzen, I., \& Fishbein, M. (2005). The influence of attitudes on behavior.

Al Rabaa'i, A. A. (2016) Extending the Technology Acceptance Model (TAM) to assess students' behavioural intentions to adopt an e-learning system: The case of Moodle as a learning tool. Journal of Emerging Trends in Engineering and Applied Sciences, 7(1), 13-30.

Al-Adwan, A. S., \& Smedley, J. (2013). Exploring students' acceptance of e-learning using Technology Acceptance Model in Jordanian universities. International Journal of Education and Development using Information and Communication Technology, 9(2), 4-18.

Al-Gahtani, A. F. (2011). Evaluating the effectiveness of the e-learning experience in some universities in Saudi Arabia from male students' perceptions (Doctoral thesis), Durham University.

Al-Gahtani, S. S. (2008). Testing for the applicability of the TAM Model in the Arabic context: exploring an extended TAM with three moderating factors. Information Resources Management Journal, 21(4), 126. https://doi.org/10.4018/irmj.2008100101

Al-Gahtani, S. S. (2016). Empirical investigation of elearning acceptance and assimilation: A structural equation model. Applied Computing and Informatics, 12(1), 27-50. https:/ / doi.org/10.1016/j.aci.2014.09. 001

Al-Gahtani, S. S., Hubona, G. S., \& Wang, J. (2007) Information Technology (IT) in Saudi Arabia: culture and the acceptance and use of IT. 
Information $\mathcal{E} \quad$ Management, 44(8), 681-691. https:/ / doi.org/10.1016/j.im.2007.09.002

AlHamad, A. Q. M. (2020). Acceptance of e-learning among university students in UAE: A practical study. International Journal of Electrical and Computer Engineering (IJECE), 10(4), 3660-3671. https:// doi.org/10.11591/ijece.v10i4

Al-Harbi Al-Siraihi, K. (2011). E-learning in the Saudi tertiary education: Potential and challenges. Applied Computing and Informatics, 9(1), 31-46. https://doi.org/10.1016/j.aci.2010.03.002

Al-Hawari, M., \& Mouakket, S. (2010). The influence of technology acceptance model (TAM) factors on students' e-satisfaction and e-retention within the context of UAE e-learning. Education, Business and Society: Contemporary Middle Eastern Issues, 3(4), 299-314.

https:/ / doi.org/10.1108/17537981011089596

Almaiah, M. A., \& Alismaiel, O. A. (2019). Examination of factors influencing the use of mobile learning system: An empirical study. Education and Information Technologies, 24(1), 885-909. https:/ / doi.org/10.1007/s10639-018-9810-7

Almaiah, M. A., \& Jalil, M. A. (2014). Investigating students' perceptions on mobile learning services. International Journal of Interactive Mobile Technologies, 8(4), 31-36. https://doi.org/10.3991/ ijim.v8i4.3965

Almaiah, M. A., Al-Khasawneh, A., \& Althunibat, A. (2020). Exploring the critical challenges and factors influencing the E-learning system usage during COVID-19 pandemic. Education and Information Technologies, 25, 5261-5280. https://doi.org/ 10.1007/s10639-020-10219-y

Al-Qaysi, N., Mohamad-Nordin, N., \& Al-Emran, M. (2018). A systematic review of social media acceptance from the perspective of educational and information systems theories and models. Journal of Educational Computing Research, 57(8), 20852109.

\section{https: / / doi.org/10.1177\%2F0735633118817879}

Alshammari, S. H., Ali, M. B., \& Rosli, M. S. (2016). The influences of technical support, self-efficacy and instructional design on the usage and acceptance of LMS: A comprehensive review. Turkish Online Journal of Educational Technology-TOJET, 15(2), 116125.

Arkorful, V., \& Abaidoo, N. (2014). The role of elearning, the advantages and disadvantages of its adoption in higher education. International Journal of Education and Research, 2(12), 397-410.

Baker, E. W., Al-Gahtani, S. S., \& Hubona, G. S. (2010). Cultural impacts on acceptance and adoption of information technology in a developing country.
Journal of Global Information Management, 18(3), 3558. https://doi.org/10.4018/jgim.2010070102

Barclay, D. C., Higgins, C. A., \& Thompson, R. (1995). The partial least squares approach to causal modeling: Personal computer adoption and use asan illustration. Technology Studies, Special Issues on Research Methodology, 2, 282-324.

Bares, A. (2008). Compensation force (blog). Companies spend an average of $\$ 1,202$ per employee on training. http://compforce.typepad.com/compen sation_force/2008/02/companies-spend.html

Bokolo Jr, A., Kamaludin, A., Romli, A., Mat Raffei, A. F., A/L Eh Phon, D. N., Abdullah, A., Ming, G. L., Shukor, N. A., Nordin, M. S., \& Baba, S. (2020). A managerial perspective on institutions' administration readiness to diffuse blended learning in higher education: Concept and evidence. Journal of Research on Technology in Education, 52(1), 37-64. https://doi.org/10.1080/ 15391523.2019.1675203

Boud, D., Cohen, R., \& Sampson, J. (1999). Peer learning and assessment. Assessment $\mathcal{E}$ Evaluation in Higher Education, 24, 413-426. https://doi.org/10.1080/ 0260293990240405

Calisir, C. A., Gumussoy, A. E., Bayraktaroglu, and Karaali,D ( 2014). Predicting the intention to use a Web-based learning system: Perceived content quality, anxiety, perceived system quality, image, and the technology acceptance model. Human Factors and Ergonomics in Manufacturing $\mathcal{E}$ Service Industries, 24(5), 515-531. https:/ / doi.org/10.1002/ hfm.20548

Carswell, A. D., \& Venkatesh, V. (2002). Learner outcomes in an asynchronous distance educational environment. International Journal of HumanComputer Studies, 56(5), 475-494. https://doi.org/ 10.1006/ijhc.2002.1004

Chen, H., \& Li, Y. (2018). A research on factors influencing online education users' continuance usage intention. Journal of Education and Practice, 9(14), 37-42. https://www.iiste.org/Journals/ index.php/JEP/article/download/42383/43649

Cheng, M. Y. (2011). Antecedents and consequences of elearning acceptance. Information Systems Journal, 21(3), 269-299. https://doi.org/10.1111/j.13652575.2010.00356.x

Cheng, T. C., Hajiyev, J., \& Chia-Rong, S. (2017). Examining the students' behavioral intention to use e-learning in Azerbaijan? The General Extended Technology Acceptance Model for E-learning approach. Computer $\mathcal{E}$ Education, 111, 128-143. https://doi.org/10.1016/j.compedu.2017.04.010

Chien, T.-C. (2012). Computer self-efficacy and factors influencing e-learning effectiveness. European 
Journal of Training and Development, 36(7), 670-686. https:/ / doi.org/10.1108/03090591211255539

Chin, W. (1998). The partial least squares approach to structural equation modelling. In G. A. Marcoulides (Ed.), Modern methods for business research (pp. 295-358). Lawrence Erlbaum Associates.

Chunjaun, Z., \& Zongxiang, M. (2016). A case study of American and Chinese college students' motivation differences in online learning environment. Journal of Education and Learning, 5(4), 104-112. https://doi.org/10.5539/jel.v5n4p104

Davis, F. D. (1989). Perceived usefulness, perceived ease of use, and user acceptance of information technology. MIS Quarterly, 13(3), 319-340. https:/ / doi.org/10.2307/249008

Davis, F. D., Bagozzi, R. P., \& Warshaw, P. R. (1989). User acceptance of computer technology: A comparison of two theoretical models. Management Science, 35(8), 982-1002. https://doi.org/10.1287/mnsc.35. 8.982

El Elkaseh, A. M., Wong, K. W., \& Fung, Ch. Ch. (2016). Perceived ease of use and perceived usefulness of social media for e-learning in Libyan higher education: A structural equation modeling analysis. International Journal of Information and Education Technology, 6(3), 192-199. https:// doi.org/10.7763/IJIET.2016.V6.683

El-Seoud, S., Taj-Eddin, I., Seddiek, N., Ghenghesh, P., \& El-Khouly, M. (2014). The impact of e-learning on Egyptian higher education and its effect on learner's motivation: A case study. Computer Science and Information Technology, 2(3), 179-187. https:/ / doi.org/10.13189/csit.2014.02030

Fathema, N., Shannon, D., \& Ross, M. (2015). Expanding The Technology Acceptance Model (TAM) to examine faculty use of learning management systems (LMSs) in higher education institutions. MERLOT Journal of Online Learning and Teaching, 11(2), 210-232.

Hair, J., Black, W., Babin, B., Anderson, R., \& Tatham, R. (2006). Multivariate data analysis. Pearson Prentice Hall.

Harandi, S. R. (2015) Effects of e-learning on students' motivation. Procedia - Social and Behavioral Sciences, 181, 423-430. https://doi.org/10.1016/j.sbspro. 2015.04.905

Holden, H. (2011). Understanding the influence of perceived usability and technology self-efficacy on teachers' technology acceptance. Journal of Research on Technology in Education, 43(4), 343-367. https:// doi.org/10.1080/15391523.2011.10782576

Hoyle, R. H., \& Panter, A. T. (1995). Writing about structural equation models. In R. H. Hoyle (Ed.), Structural equation modelling (pp. 158-176). Sage.
Huang, H. M., \& Liaw, S. S. (2005). Exploring users' attitudes and intentions toward the Web as a survey tool. Computers in Human Behavior, 21(5), 729-743. https:// doi.org/10.1016/j.chb.2004.02.020

Junus, I. S., Santoso, H. B., Yugo K. Isal, R., \& Utomo, A. Y. (2015). Usability evaluation of the student centered e-learning environment. International Review of Research in Open and Distance Learning, 16(4), 62-82. https:// doi.org/10.19173/irrodl.v16i4 .2175

Juwah, C. (2006). Interactions in online peer learning. In C. Juwah (Ed.), Interactions in online education (pp. 171-190). Routledge. https://doi.org/10.4324/ 9780203003435

Keller, J. M., \& Suzuki, K. (2004). Learner motivation and e-learning design: A multinational validated process. Journal of Educational Media, 29(3), 229-239. https://doi.org/10.1080/1358165042000283084

Khor, E. T. (2014). An analysis of ODL student perception and adoption behavior using the technology acceptance model. International Review of Research in Open and Distance Learning, 15(6), 275288. https:// doi.org/10.19173/irrodl.v15i6.1732

King, W. R., \& He, J. (2006). A meta-analysis of the Technology Acceptance Model. Information $\mathcal{E}$ Management, 43(6), 740-755. https://doi.org/ 10.1016/j.im.2006.05.003

Krejcie, V., \& Morgan, D. W. (1970). Determining sample size for research activities. Educational and Psychological Measurement, 30(3), 607-610. https:// doi.org/10.1177/001316447003000308

Lai, P. C. (2017). The literature review of technology adoption models and theories for the novelty technology. Journal of Information Systems and Technology Management, 14(1), 21-38. https://doi. org/10.4301/S1807-17752017000100002

Lay, J. G., \& Chen, Y. W. (2011, October). GIS adoption and diffusion among senior high school geography teachers in Taiwan. In P. Shih (Ed.), ISPRS Workshop Commissions VI/1 - VI/2 E-learning 2011 with ACRS. http://www.isprs.org/proceedings/XXXVIII/6W27/pdf/P_41_8-16-19.pdf

Lee, Y. (2006). An empirical investigation into factors influencing the adoption of an e-learning system. Online Information Review, 30(5), 517-541. https:// doi.org/10.1108/14684520610706406

Lee, Y., Kozar, K. A., \& Larsen, K. (2003). The Technology Acceptance Model: Past, present, future. Communication of the Associations for Information Systems, 12, 752-780. https://doi.org/10.17705/1CAIS.01250

Lin, Y.-C., Chen, Y.-C., \& Yeh, R. C. (2010). Understanding college students' continuing intentions to use multimedia E-learning systems. 
World Transactions on Engineering and Technology Education, 8(4), 488-493.

Liu, I.-F., Chen, M. C., Sun, Y. S., Wible, D., \& Kuo, C.-H. (2010). Extending the TAM model to explore the factors that affect intention to use an online learning community. Computers E Education, 54(2), 600-610. https://doi.org/10.1016/j.compedu.2009.09.009

Lu, J., Yu, C., Liu, C., \& Yao, J. E. (2003). Technology acceptance model for wireless Internet. Internet Research: Electronic Networking Applications and Policy, 13(3), 206-222. https://doi.org/10.1108/ 10662240310478222

Mohammadi, H. (2015). Investigating users' perspectives on e-learning: An integration of TAM and IS success model. Computers in Human Behavior, 45, 359-374. https://doi.org/10.1016/j.chb.2014.07. 044

Nafsaniath, F., \& Shannon. D. (2015). Expanding the Technology Acceptance Model (TAM) to examine faculty use of Learning Management Systems (LMSs) in higher education institutions. MERLOT Journal of Online Learning and Teaching, 11(2), 210232.

Nath, R., Bhal, K. T., \& Kapoor, G. T. (2014). Factors influencing IT adoption by bank employees: An extended TAM approach. Vikalpa, 38(4), 83-96. https://doi.org/10.1177/0256090920130406

Oblinger, D. G., \& Hawkins, B. L. (2005). The myth about e-learning. Edu cause review.

Ong, C.-H., \& Lai, J. Y. (2006). Gender differences in perceptions and relationships among dominants of e- learning acceptance Computer in Human Resource, 22(5), 816-829. https:/ / doi.org/10.1016/j.chb.2004. 03.006

Paechter, M., Marier, B. \& Macher, M (2020) Students' expectations of, and experiences in e-learning: Their relation to learning achievements and course satisfaction. Computer \& Education 54(1) 222-229. https://doi.org/10.1016/j.compedu.2009.08.005

Pham, L., Limbu, Y. B., Bui, T. K., Nguyen, H. T., \& Pham, H. T. (2019). Does e-learning service quality influence e-learning student satisfaction and loyalty? Evidence from Vietnam. International Journal of Educational Technology in Higher Education, 16, 7. https:/ / doi.org/10.1186/s41239-019-0136-3

Ringle, M., Wende, S., \& Becker, J.-M. (2015). SmartPLS 3. Bönningstedt: SmartPLS. Technical Report.

Roca, J. C., Chiu, C. M., \& Jose-Martinez Lopez, F. (2006). Understanding e-Learning continuance intention: An extension of the technology acceptance model. International Journal of Human-Computer Studies, 64(8), 683-696. https://doi.org/10.1016/j.ijhcs. 2006.01.003

Rym, B., Bouzaabia, O., \& Mélika, B. M. (2013). Determinants of E-learning acceptance: An empirical study in the Tunisian context. American Journal of Industrial and Business Management, 3(3), 307-321.

https://doi.org/10.4236/ajibm.2013.33036

Salajan, F. D., Welch, A. G., Ray, C. M., \& Peterson, C. (2015). The role of peer influence and perceived teaching quality in faculty acceptance of web-based learning management systems. International Journal on E-Learning, 14(4), 487-524.

Salloum, S. (2018). Investigating students' acceptance of Elearning system in Higher Educational Environments in the UAE: Applying the Extended Technology Acceptance Model (TAM) [MSc dissertation]. The British University in Dubai.

Salloumi, S., AlHamad, A. Q. M., Al-Emran, M., Abdel Monem, A., \& Shaalan, K. (2019). Exploring students' acceptance of e-learning through the development of a comprehensive technology acceptance model. IEEE Access, 7, 128445-128462. https://doi.org/10.1109/ ACCESS.2019.2939467

Sangrà, A., Vlachopoulos, D., \& Cabrera, N. (2012). Building an inclusive definition of e-learning: An approach to the conceptual framework. The International Review of Research in Open and Distributed Learning, 13(2), 145-159. https:// doi.org/10.19173/irrodl.v13i2.1161

Schunk, D. H., Meece, J. L., \& Pintrich, P. R. (2014). Motivation in education: Theory, research, and applications (4th ed.). Pearson.

Shawai, Y. G., \& Almaiah, M. A. (2018). Malay language mobile learning system (MLMLS) using NFC technology. International Journal of Education and Management Engineering, 8(2), 1. https://doi.org/ 10.5815/ijeme.2018.02.01

Shen, D., Laffey, J., Lin, Y., \& Huang, X. (2006). Social influence for perceived usefulness and ease-of-use of course delivery systems. Journal of Interactive Online Learning, 5(3), 270-282. http://www.ncolr. org/jiol/issues / getfile.cfm?volID=5\&IssueID=18 \&ArticleID $=91$

Singh, G., O'Donoghue, J., \& Worton, H. (2005). A study into the effects of e-learning on higher education. Journal of University Teaching E Learning Practice, 2(1), 3. https:/ / doi.org/10.53761/1.2.1.3

Sorebo, O., Halvari, H., Gulli, V. F., \& Kristiansen, R. (2009). The role of self-determination theory in explaining teachers' motivation to continue to use elearning technology. Computers E Education, 53(4), 1177-1187. https:/ / doi.org/10.1016/j.compedu.2009.06.001

Sun, P. C., Tsai, R. J., Finger, G., Chen, Y.-Y., \& Yeh, D. (2008). What drives a successful eLearning? An empirical investigation of the critical factors influencing learner satisfaction. Computers $\mathcal{E}$ 
Education, 50(4), 1183-1202. https://doi.org/ 10.1016/j.compedu.2006.11.007

Teo, T., \& Zho, M. (2014). Explaining the intention to use technology among university students: A structural equation modeling approach. Journal of Computing in Higher Education, 26(2), 124-142. https://doi.org/10.1007/s12528-014-9080-3

Thatcher, J. B., \& Perrewé, P. L. (2002). An empirical examination of individual traits as antecedents to computer anxiety and computer self-efficacy. MIS Quarterly, 26(4), 381-396. https:// doi.org/10.2307/ 4132314

Turner, M., Kitchenham, B., Brereton, P., Charter, S., \& Budgen, D. (2010). Does the technology acceptance model predict actual use? A systematic literature review. Information and Software Technology, 52(5), 436-479.

https:// doi.org/10.1016/j.infsof.2009.11.005

Venkatesh, V. (1999). Creation of favorable user perceptions: exploring the role of intrinsic motivation. Management Information Systems Quarterly, 23(2), 239-260. https:/ / doi.org/10.2307/ 249753

Venkatesh, V. (2000). Determinants of perceived ease of use: Integrating control, intrinsic motivation, and emotion into the technology acceptance model. Information Systems Research, 11(4), 342-365. https:// doi.org/10.1287/isre.11.4.342.11872

Venkatesh, V., \& Bala, H. (2008). Technology Acceptance Model 3 and a Research Agenda on Interventions. Decision Sciences, 39(2), 273-315. https://doi.org/ 10.1111/j.1540-5915.2008.00192.x

Venkatesh, V., \& Davis, F. D. (1999). A model of the antecedents of perceived ease of use: Development and test. Decision Sciences, 27(3), 451-481. https:// doi.org/10.1111/j.1540-5915.1996.tb01822.x

Venkatesh, V., \& Davis, F. D. (2000). A theoretical extension of the technology acceptance model: Four longitudinal field studies. Management Science, 46(2), 186-204. https:// doi.org/10.1287/mnsc.46.2. 186.11926

Venkatesh, V., \& Davis, F. D. (2000). A theoretical extension of the technology acceptance model four longitudinal field studies. Management Science, 46(2), 186-204. https:// doi.org/10.1287/mnsc.46.2. 186.11926

Venkatesh, V., Davis, F. D., \& Morris, M. G. (2007). Dead or alive? The development, trajectory and future of technology adoption research. Journal of Association for Information Systems, 8(4), 267-286. https://doi.org/10.17705/1jais.00120

Venkatesh, V., Morris, M. G., Davis, G. B., \& Davis, F. D. (2003). User acceptance of information Technology Toward a unified view. motivation. Management
Information Systems Quarterly, 27(3), 426-478. https:/ / doi.org/10.2307/30036540

Venkatesh, V., Morris, M. G., Davis, M. G., \& Davis, F. D. (2003). User acceptance of information technology: Toward a unified view. MIS Quarterly, 27(3), 425-478. https:/ / doi.org/10.2307/30036540

Vonderwell, S., \& Zachariah, S. (2005). Factors that influence participation in online learning. Journal of Research on Technology in Education, 38(2), 213230.

https:/ / doi.org/10.1080/15391523.2005.10782457

Waheed, M., \& Jam, A. F. (2010). Teachers' intention to accept online education: Extended TAM model. Interdisciplinary Journal of Contemporary Research in Business, 2, 330-344.

Waheed, M., \& Kaur, K. (2014). Knowledge quality: A review and a revised conceptual model. Information Development, 32(3), 271-284. https://doi.org/ $10.1177 / 0266666914539694$

Waheed, M., Kaur, K., Ul Ain, N., \& Hussain, N. (2015). Perceived learning outcomes from Moodle: An empirical study of intrinsic and extrinsic motivating factors. Information Development, 32(4), 1001-1013.

https:/ / doi.org/10.1177/0266666915581719

Yaldirim, S. (2000) Effects of an educational computing course on preservice and inser vice teachers: A discussion and analysis of attitudes and use. Journal of Research on Computing in Education, 32(4), 479-495. https:/ / doi.org/10.1080/08886504.2000.10782293

Young, J. (2002). Online teaching redefines faculty members' schedules, duties, and relationships with students. Chronicle of Higher Education.

Yusuf, N., \& Al-Banawi, N. (2013). The impact of changing technology: The case of e-learning. Contemporary Issues in Education Research - Second Quarter, 6(2), 173. https://doi.org/10.19030/ cier.v6i2.7726

Zaharias, P., \& Poylymenakou, A. (2009). Developing a usability evaluation method for e-learning applications: Beyond functional usability. International Journal of Human-Computer Interaction, 25(1), 75-98. https://doi.org/10.1080/10447310802 546716

Zainab, B., Awais Bhatti, M., \& Alshagawi, M. (2017). Factors affecting e-training adoption: An examination of perceived cost, computer selfefficacy and the technology acceptance model. Behaviour \& Information Technology, 36(12), 12611273.

https:/ / doi.org/10.1080/0144929X.2017.1380703

Zeitoun, S. (2015). Instructional design in science: Using scenarios in e-learning. International Journal of Humanities Social Sciences and Education, 2(8), 80-89. 
Zemsky, R., \& Massy, W. (2004). Thwarted innovation: What happened to e-learning and why. Learning
Alliance, University of Pennsylvania. http:/ / www. irhe.upenn.edu/WeatherStation.html

\section{http://www.ejmste.com}

